\title{
MAKNA DAN STRUKTUR PAKAIAN KARNAVAL JOGJA FASHION WEEK DI YOGYAKARTA 2007-2014
}

\author{
Deni Setiawan \\ Jurusan PGSD, Fakultas Ilmu Pendidikan, Universitas Negeri Semarang \\ denijusmani@gmail.com
}

\begin{abstract}
Costume exhibition show, Jogja Fashion Week Carnival, was intended to progress clothing industry, to lessen the imported clothes, and to raise the selling value of the traditional clothes in Indonesia. Throughout 2007-2014, the costume exhibition show was adequately effective to introduce the products of traditional culture becoming local characteristics to public. The research on carnival costume was made to find out the periods of the clothing style by applying art historic approach, to explain the issue of interpretation and social interaction, I used art sociological approach. The resulted conclusion was that every style of carnival costumes reflected several meanings, such as: clothing imagery, designer, and trademark. The costume structure consists of physical and non-physical ones. The physical structure was related to the issues of style, shape, and visual appearance; while the non-physical one comprised interpretation regarding the concepts of creation, social conditions, and history. The creation of carnival costumes was influenced by social condition referring to legends, fairy tales, and the myths. In addition, the designer played essential parts, i.e. creating and constructing new fashion of carnival costume in Yogyakarta.
\end{abstract}

Keywords: carnival costume, style, the concept of creation.

\begin{abstract}
ABSTRAK
Acara pameran pakaian Karnaval Jogja Fashion Week, dimaksudkan untuk memajukan industri pakaian menekan jumlah impor pakaian asing, dan meningkatkan nilai jual kain-kain tradisional di Indonesia. Sepanjang tahun 2007-2014, acara pameran pakaian cukup efektif memperkenalkan produk budaya tradisional yang menjadi ciri khas daerah kepada masyarakat. Penelitian pakaian karnaval dilakukan untuk mengetahui periodisasi gaya pakaian dengan menggunakan pendekatan sejarah seni; untuk menguraikan persoalan pemaknaan dan interaksi sosial masyarakat, digunakan pendekatan sosiologi seni. Kesimpulan yang dihasilkan adalah setiap gaya pakaian karnaval mencerminkan beberapa makna, seperti: pencitraan kain, perancang, dan merk dagang. Struktur pakaian terdiri atas fisik dan nonfisik, struktur fisik menyangkut persoalan gaya, bentuk, dan tampilan visual, sedangkan nonfisik meliputi pemaknaan yang terkait dengan konsep penciptaan, kondisi sosial, dan sejarah. Penciptaan pakaian karnaval dipengaruhi oleh kondisi sosial yang mengacu pada legenda, dongeng, dan mitos-mitos. Selain itu terdapat peran perancang yang menciptakan dan mengkreasikan bentuk baru pakaian karnaval di Yogyakarta.
\end{abstract}

Kata kunci: pakaian karnaval, gaya, konsep penciptaan.

\section{PENDAHULUAN}

Pakaian tidak saja terdiri atas sekumpulan material kain, dengan corak, pola, dan aksesori tertentu, tetapi secara mendalam dapat memperlihatkan berbagai macam persoalan. Pakaian dapat menampilkan kesenangan, kegembiraan, tradisi, dan termasuk di dalamnya adalah pemberontakan dan per- lawanan. Uraian Dick Hebdige pada salah satu sub bab di Subculture: The Meaning of Style, adalah persoalan pemberontakan atau perlawanan yang dilakukan melalui gaya berpakaian, musik, dan komunitas (2005: 201-204)). Pakaian merupakan sub-budaya dari kebudayaan yang lebih luas, memiliki peran penting perlawanan terhadap konstruksi sosial budaya tertentu, mini- 
mal terhadap konvensi pakaian.

Tentu, pakaian karnaval tidak diciptakan untuk melakukan pemberontakan dalam hal sesungguhnya, tetapi untuk mengkreasi dan menciptakan alternatif bentuk pakaian. Pemberontakan merupakan perlawanan atas konvensi gaya pakaian konvensional atau kasual, dan diciptakan gaya pakaian dengan corak dan variasi yang beraneka ragam, warna-warni, serta bermacam-macam aksesori, sehingga memberi ruang bagi peningkatan nilai tekstil tradisional. Stagnannya tekstil tradisional, dikarenakan kurangnya kreativitas dan inovasi yang dilakukan. Pelaksanaan pameran pakaian melalui Karnaval Jogja Fashion Week (KJFW) dari tahun ke tahun, sebagai bentuk pemberontakan terhadap konvensi pakaian, memberikan ruang kreativitas dan inovasi untuk meningkatkan nilai jual tekstil tradisional. Konteks tema yang diketengahkan selalu sama, yaitu bagaimana mengangkat dan memperluas potensi ekonomi kain-kain tradisional di Indonesia, memperkenalkan budaya tradisi, berperan serta dalam menciptakan lapangan kerja, memajukan industri pakaian, menekan laju impor tekstil asing, dan memberikan ruang perkembangan ekonomi kreatif. Seperti diketahui, bahwa impor tekstil dari Cina dan India sudah dimulai pada abad ke-15 sampai abad ke-17 (Syukur, dkk, 2014: 63-77).

Gagasan pokok acara KJFW berkaitan erat dengan kegiatan Jogja Fashion Week (JFW). Acara pameran pakaian pada JFW merupakan salah satu bentuk promosi produk kebudayaan dan menggali potensi industri dan ekonomi kreatif bidang pakaian. Acara JFW dan KJFW dibentuk berdasarkan atas keadaan produk pakaian lambat berkembang dan industri pakaian yang cenderung menurun. Konsep lain berdasarkan atas menurunnya jumlah pengrajin pada sentra industri rumah tangga, yang menghasilkan batik dan tenun lurik, kalah dari perkembangan tekstil hasil industri mesin. Berdasarkan gagasan dan prakarsa Gusti Kanjeng Ratu Pembayun, Afif Syakur dan Isman Indarto, serta di dukung oleh Balai Pelayanan Bisnis Dinas Perindustrian Perdagangan dan Koperasi, Dinas Pariwisata Provinsi Daerah Istimewa Yogyakarta (DIY), dan Dinas Pendidikan dan Budaya, acara JFW dilaksanakan untuk pertama kali pada tahun 2006 (jogjanews.com).

Perjalanan acara JFW menampilkan perubahan konsep acara dari tahun ke tahun, menyesuaikan dengan tematema yang ditentukan oleh panitia penyelenggara, sebagai usaha untuk menyajikan kondisi sosial berdasarkan temuan pada masyarakat. Pada tahun 2007, acara pada JFW dikembangkan menjadi dua jenis, yaitu: fashion show dan karnaval pakaian, tetapi tetap menjadi satu rangkaian acara. Acara JFW melalui fashion show, menampilkan kreasi perancang pakaian Yogyakarta, yang bertujuan untuk mempromosikan produk terbaru dan dapat digunakan secara umum, sesuai fungsi pokok pakaian. Acara karnaval pakaian pada JFW, lebih dikenal sebagai KJFW, merupakan sebuah acara memamerkan rancangan pakaian yang ditampilkan dalam bentuk desain sebagai karya seni, bentuk ekspresi seniman (perancang pakaian) pada wilayah publik.

Pakaian karnaval memiliki struktur fisik dan struktur sosial. Berdasarkan pada "struktur" yang dibicarakan oleh Desmond Morris, pakaian dapat dilihat dari persoalan kenyamanan, kesopanan, dan benda untuk dipamerkan (2002: 320). Pakaian karnaval sekalipun, walaupun menjadi produk dan sebagai ungkapan ekspersi perancang pakaian dalam wujud karya seni, tetap memperhatikan struktur nya- 
man, situasi, dan tujuan diciptakan. Struktur pada persoalan nyaman dalam konteks fisik dan psikologis, merupakan bagian dari konsep penciptaan dan penggunaan pakaian pada masyarakat atau konsumen tertentu. Nyaman fisik, belum tentu dapat nyaman secara psikologis. Secara fisik, nyaman ini dapat diterjemahkan dengan mengacu pada unsur-unsur desain, seperti: ukuran yang pas, tidak mengganggu dan memberi rasa aman. Berbeda dalam konteks psikologis, dapat terkait dengan persoalan budaya, agama, sosial, politik, dan tujuan ekonomi. Demikian pula bagian kesopanan dan pameran, pakaian karnaval sebagai produk seni tidak terlepas dari konteks kelayakan sosial dan penempatan ketika pakaian tersebut dipamerkan kepada masyarakat konsumen, ataupun masyarakat penonton. Dengan demikian, pakaian karnaval dapat dilihat melalui tanda-tanda, halhal yang menjadi penanda dan yang ditandai.

Persoalan penanda dan hal yang ditandai dalam pakaian karnaval, dapat diuraikan menurut pandangan Roland Barthes, melalui dua level atau tatanan signifikasi. Pada tatanan pertama telah dijelaskan Ferdinand de Saussure (hal yang ditandai dan penanda) dan tatanan kedua bukan menyangkut katakata itu sendiri, tetapi asosiasi dengan sekitarnya. Teori de Saussure menekankan teks, bukan kekayaan makna, tidak menjelaskan ambiguitas dan kesan. Barthes menjelaskan tatanan de Saussure masuk kategori denotasi, berdasarkan makna sehari-hari yang jelas dan sesuai akal sehat. Penanda dan petanda (yang ditandai) bersama-sama membentuk tanda, dan digunakan dalam rangkaian tanda untuk menghasilkan berbagai makna. Makna denotasi pada pakaian dapat dilihat berdasarkan tampilan fisik, kajian desain dapat menguraikan persoalan tersebut, sehingga diketahui jenis bahan, ragam hias, aksesori, dan hal-hal yang menyangkut persoalan fisik. Tatanan kedua, sesuai identifikasi Barthes, masuk pada wilayah konotasi. Keseluruhan tanda yang diciptakan dalam denotasi menjadi penanda bagi babak kedua, yaitu pemunculan makna. Di sinilah terdapat peran pembaca, pendengar, atau pengamat tanda untuk memahami dan dalam rangka menafsirkan. Barthes berpendapat, bahwa signifikasi tatanan kedua inilah yang menciptakan mitos-mitos (Will Barton dan Andrew Beck, 2010: 107-110). Wilayah konotasi inilah yang dapat diperluas kembali melalui kajian unsur-unsur, sehingga dapat menguraikan persoalan makna-makna pada pakaian karnaval.

Penelitian pakaian KJFW bukanlah penelitian sejarah, tetapi aspek kesejarahaan tidak dapat dihindari, untuk memperlihatkan rangkaian perjalanan ide perancang, periodisasi gaya, dan konsep-konsep penciptaan pakaian. Sejarah dibedakan dalam tiga jenis, yaitu: sejarah mentalitas, sejarah sosial, dan sejarah struktural. Terdapat dua hal sejarah dalam penelitian ini, yaitu: sejarah mentalitas dan sejarah sosial. Sartono Kartodidjo menggambarkan mentalitas sebagai suatu kompleks dari sifat-sifat sekelompok manusia menonjolkan watak tertentu, yang dimanifestasikan sebagai sikap atau gaya hidup, sehingga setiap zaman pasti memiliki mentalitas yang berbeda-beda. Sejarah mentalitas mengutamakan bagaimana ide atau semangat itu mempengaruhi proses sejarah, kaitan atau interaksi antara ide dan aksi, tidak memberikan kesan seakan-akan ide dapat hidup dan tumbuh sendiri dari kehidupan manusia (Kartodirdjo, 2002: 5). Sejarah sosial dimaksudkan untuk melihat perubahan paradigma sosial, yang mempengaruhi konsep berpikir dan landasan penciptaan pakaian. Perubahan sosial akan 
Makna dan Struktur ... - Deni Setiawan

berpengaruh dan memiliki ikatan tertentu dengan acara pameran pakaian KJFW.

Menurut Arnold Hauser, peristiwa sejarah seni yang paling fundamental adalah perubahan gaya dan selera, sebuah fenomena dialektikal yang tidak dapat diragukan, suatu hasil dari tendensi-tendensi kontradiktif. Konsep sejarah seni yang inti dan fundamental yaitu gaya kolektif dari suatu periode, memiliki makna dialektika lebih ketat, sebab mendapat maknanya pada bagian terbesar dalam konflik antara tendensi dan gerakan yang dialami (Hauser, 1982: 409). Pemahaman tentang seni dapat berubah karena adanya perubahan kondisi, pemikiran baru, perasaan, dan kehidupan. Sebuah karya seni diciptakan dan memperoleh pengaruh dari sejarah saat seni itu diciptakan. Seni memiliki karakter sesuai sejarahnya dan bentuk-bentuk seni yang dipresentasikan, akan berbeda-beda sesuai dengan tingkatan dimana sebuah masyarakat pemiliki kesenian tersebut berhubungan dengan orang lain (Hauser, 1982: 70-72).

Pakaian karnaval memiliki konteks makna yang tidak muncul karena gejala sosial budaya tertentu, melainkan menjadi sebuah pemikiran dalam material berwujud karya seni. Misalnya: aplikasi kain batik pada pakaian karnaval, sebetulnya dimunculkan sebagai upaya menaikkan citra dan harga jual kepada masyarakat umum. Kain batik sendiri menjadi lebih populer setelah menjadi bagian dari masyarakat umum, menjadi bagian dalam kebudayaan rakyat. Kebudayaan rakyat dapat dilihat sebagai produk seni yang berkembang di desa-desa, di luar lingkar istana atau pusat-pusat kesenian, yang menjadi penyangga produk kebudayaan yang adiluhung (Warto, Jurnal Paramita, Volume 24, Nomor 1, Januari 2014, 47-62).

\section{METODE PENELITIAN}

Penelitian Struktur dan Makna Pakaian KJFW berjenis data kualitatif, dengan pendekatan teori sejarah seni dan sosiologi seni. Pengumpulan data pokok penelitian dilakukan melalui pengamatan langsung pada tahun 20092014, yang diperkuat dengan data tertulis, sedangkan tahun 2007-2008 pengumpulan data dilakukan melalui sumber tertulis, termasuk menggunakan nara sumber dengan cara wawancara tertulis dan lisan. Pengumpulan data-data dari sumber pustaka, baik data cetak dan data elektronik, dilakukan dan di analisis berdasarkan kebutuhan ilmiah penelitian. Data cetak bersumber, seperti: majalah, tabloid, jurnal, dan koran, sedangkan data elektronik bersumber pada televisi, media massa elektronik, yang diakses melalui internet. Nara sumber ditentukan berdasarkan partisipasi dan peran serta terhadap acara KJFW, baik sebagai perancang pakaian, peserta karnaval, maupun sebagai panitia penyelenggara.

\section{HASIL DAN PEMBAHASAN}

\section{Pakaian Karnaval Jogja Fashion Week Tahun 2007-2014}

Acara Karnaval Jogja Fashion Week, pada setiap penyelenggaran memiliki konsep yang menarik, hal ini dilakukan untuk menghindari pengulangan tema, menghindari kejenuhan, dan mengolah kreativitas baru dalam penciptaan pakaian, untuk memberikan inspirasi bagi pihak-pihak lain. Dinas Pariwisata Daerah Istimewa Yogyakarta dan tim, selaku pelaksana kegiatan selalu mengganti orang-orang yang bertanggung jawab dalam pelaksanaan acara KJFW, sehingga selalu muncul pemikiran baru untuk memajukan industri pakaian di 
Yogyakarta. Beberapa pihak yang sering berperan serta dalam acara KJFW, seperti: Asosiasi Perancang dan Pengusaha Mode Indonesia (APPMI) Yogyakarta, ahli-ahli perancang pakaian yang memiliki pengalaman, untuk mendapatkan hasil maksimal pada pelaksanaan acara KJFW. Periodisasi karakter pakaian dan pelaksanaan pameran pakaian KJFW dari tahun 2007-2014, sebagai berikut.

\section{Karakter Pakaian KJFW 2007}

Acara pameran pakaian KJFW, masih mencari bentuk, sistem pelaksanaan, dan hal teknis lainnya, dengan acuan pada beberapa acara, seperti: Jogja Java Carnival dan Jember Fashion Carnival. Acara KJFW tahun 2007 berkaitan erat dengan konsep dan tema pada acara Jogja Fashion Week, karena masih satu rangkaian acara yang diprogram oleh Pemerintah Daerah Yogyakarta dan memiliki tujuan sama. Demikian pula pada peserta yang berperan dalam kegiatan tersebut, sebagian besar masih pelaku dan pebisnis industri rancang pakaian, selain terdapat beberapa organisasi masyarakat, seperti: paguyuban masyarakat Jawa Barat di Yogyakarta, paguyuban sepeda onthel. Pada awalnya acara KJFW merupakan pawai dari pengusaha pakaian, dengan menggunakan 20 andhong yang di hias. Setiap andhong menampilkan pakaian dari beberapa perancang pakaian, seperti karya: Hamzah Batik, Afif Syakur, dan Lia Mustafa. Andhong sendiri merupakan ide yang di gagas oleh Hamzah Batik, selain memudahkan dalam promosi, kendaraan ini sangat familiar di Yogyakarta, khususnya di wilayah Malioboro, yang menjadi tempat pelaksanaan KJFW. Karena acara berlangsung sukses, Dinas Pariwisata Kota Yogyakarta, merespon kegiatan karnaval tersebut secara posi- tif, yang pada akhirnya dijadikan sebagai agenda tahunan, untuk promosi kebudayaan, pertunjukan wisata, promosi sekolah, promosi hotel, dan kepentingan bisnis industri pakaian.

Tema Essentially Global dimaksudkan sebagai upaya para perancang untuk mengetengahkan beberapa hasil kebudayaan tradisional masyarakat, yaitu: kain batik, kain rajutan, dan kain tenun, yang dimiliki oleh beberapa daerah di Indonesia. Kain-kain tersebut di olah dan dipadukan dengan beberapa material lain, seperti: plastik, kain parasut, dan tikar, dibuat menjadi sebuah pakaian karnaval yang mengandung nilai seni. Tema-tema pakaian yang diangkat terkait dengan identitas nusantara, yang mengacu pada kepercayaan, legenda, mitologi, dan cerita rakyat Indonesia. Pemerintah belum memberikan bantuan apapun, kecuali sebagai fasilitator.

\section{Karakter Pakaian KJFW 2008}

Tema yang diketengahkan terkait dengan Culturally Plural, usaha untuk menampilkan kekayaan dan pakaian etnis dari beberapa kepulauan di Indonesia. Acara KJFW berupa karnaval yang menampilkan beberapa bentuk pakaian dengan citra seni tinggi, diikuti dengan penampilan drum band, parade kesenian dari beberapa sekolah, agen model, perguruan tinggi, organisasi masyarakat, pihak perhotelan, dan industri rumah tangga. Rombongan karnaval terdiri dari 15 kelompok pejalan kaki (kelompok kesenian atau sekolah/ perguruan tinggi), 28 andhong hias dengan seorang peraga yang membawakan desain terbaik (maskot) dengan sifat fantasi dari salah seorang perancang pakaian, serta terdapat 100 sepeda onthel. 
Makna dan Struktur ... - Deni Setiawan

\section{Karakter Pakaian KJFW 2009}

Boedaja in Motion merupakan acuan tema yang terpilih pada penyelenggaraan acara KJFW tahun 2009. Acara ini difokuskan untuk mengangkat eksistensi kain batik nusantara, yang bersumber dari beberapa daerah di Indonesia. Kain tradisional dari beberapa daerah tersebut di kreasi kembali menjadi bentuk pakaian seni dengan berbagai macam bentuk desain, sebagai upaya untuk menghadirkan nilai-nilai tradisi pada pakaian modern. Tahun 2009 mendapat dukungan dan sponsor dari pihak swasta (penyedia jasa telekomunikasi), dengan mengadakan Lomba Fotoblogging berkaitan dengan acara JFW, termasuk peliputan foto dalam rangkaian acara KJFW, hadiah yang diperebutkan sejumlah 11 Juta rupiah. Acara tahun ini dimeriahkan oleh 30 andhong hias dan 20 kelompok peserta karnaval.

Beberapa kelompok yang terkait dengan acara KJFW 2009, di antaranya: Kelompok Sekolah Tinggi Pariwisata Ambarrukmo Jogja (StiPram) yang menampilkan beraneka ragam desain, mulai pakaian etnik warna cerah dengan membawa kipas dan topi kipas, punggawa kerajaan dengan pakaian serba hitam dan membawa tongkat, mengantarkan sepasang pengantin yang dihiasi lukisan warna-warni. Selain itu, terdapat SMK Karya Rini Yogyakarta menampilkan pakaian dalam nuansa warna matahari sore, dengan memakai corak batik coklat tua sebagai pakaian utama, ditambahkan selempang kain transparan oranye untuk mempertegas desain. Dilengkapi pula dengan peran serta SMK Negeri 6 Yogyakarta yang memainkan unsur bulu ayam warna-warni sebagai dominasi balutan pakaian, lengkap dengan topi gaya gadis Meksiko, pertunjukannya diiringi oleh musik rebana.

\section{Karakter Pakaian KJFW 2010}

Tema yang diketengahkan pada tahun 2010 adalah Save Our Planet, usaha yang dilakukan untuk mengajak masyarakat untuk lebih mencintai, menghargai, dan sayang terhadap bumi. Kegiatan ini di gagas oleh Lia Mustafa dan Deni Setiawan. Misi utama dari KJFW 2010 adalah bagaimana memanfaatkan dan mengolah bahan-bahan yang tidak terpakai, menjadi satu set pakaian karnaval, dengan konsep recycle fashion. Kegiatan ini diharapkan mampu memberikan manfaat bagi keseimbangan dan keselamatan bumi, melalui usaha kecil dengan dampak yang besar, yaitu: menggunakan bahan limbah plastik sebagai bahan pakaian. Perlu diketahui, bahwa plastik merupakan limbah yang sangat berbahaya, hanya dapat diuraikan oleh bumi dalam waktu 500 tahun. Jika tidak dikurangi dengan segera, sampah plastik akan mengganggu stabilitas dan keseimbangan ekosistem, serta berdampak buruk bagi kesehatan lingkungan. Oleh sebab itu, plastik merupakan bahan utama yang digunakan pada acara KJFW tahun 2010. Pawai dilaksanakan masih menggunakan andhong, yang membawa karya maskot atau terbaik dari perancang pakaian acara KJFW.

\section{Karakter Pakaian KJFW 2011}

Tema KJFW pada tahun 2011 adalah Sparkling in Vintage, menggunakan perpaduan batik sebagai sentuhan vintage. "In Vintage" berarti menghadirkan rancanan pakaian dengan kekuatan tradisi masa lalu, ditampilkan dalam bentuk rancangan pakaian yang lebih populer. Pakaian populer dapat berbentuk modifikasi kebaya, modifikasi beberapa bentuk pakaian adat dari beberapa daerah di Indonesia. Bentuk- 
bentuk pakaian karnaval mengacu pada legenda dan cerita tradisi masyarakat, seperti bentuk kostum Nyi Roro Kidul, Ratu Ular, Nyi Blorong, Dewi Sri, Fantasi Mega Mendung, dan bentuk abstrak (modifikasi api). Selain kain batik, peserta pendukung karnaval menghadirkan beberapa kain dari daerah lain di Indonesia, seperti: kain tenun songket, kain rajut, dan anyaman. Penciptaan pakaian dengan rujukan tokoh dari legenda ataupun dongeng, disertai pula dengan hiasan aksesori dan make up. Sebelum melakukan pawai, rancangan terbaik diperagakan pada catwalk atau panggung yang sudah disediakan oleh panitia, untuk dilakukan penilaian dan penentuan juara. Bagi para pemenang dan nominasi mendapatkan uang pembinaan. Tahun 2011, pawai rancangan pakaian terbaik masih menggunakan andhong hias.

\section{Karakter Pakaian KJFW 2012}

Gempita Sukma Raya merupakan tema acara pameran pakaian KJFW tahun 2012, dilaksanakan di sepanjang jalan Malioboro sampai Benteng Vredeburg. Beberapa tema yang direspon dan ditampilkan oleh peserta karnaval adalah Kebaya Kartini dan Cut Nyak Dien ditampilkan oleh Keluarga Besar Waria Yogyakarta dengan berkebaya serba merah. APIP's Batik menampilkan karya berjudul Shinta Obong, berupa sosok Rama Shinta yang diikuti oleh kelompok laki-laki berpakaian merah hitam dengan ide penciptaan api. Kegiatan KJFW tahun 2012 diikuti oleh 20 kelompok, dan diberikan bantuan biaya oleh Dinas Pariwisata Yogyakarta masing-masing sebesar tiga juta rupiah per kelompok untuk memproduksi pakaian karnaval sesuai rancangan dan bimbingan yang telah ditentukan sebelumnya. Penggunaan andhong dalam pawai mulai ditiadakan, peserta pawai berjalan kaki sesuai dengan rute yang telah ditentukan. Peserta karnaval tidak saja berasal dari Yogyakarta, tetapi juga dari kota sekitarnya, seperti: Semarang, Surakarta, Pekalongan, dan Magelang.

\section{$\underline{\text { Karakter Pakaian KJFW } 2013}$}

Semarak Katulistiwa merupakan tema utama yang ditentukan oleh panitia KJFW 2013. Tema ini dibagi lagi menjadi beberapa sub tema, yaitu: Hamparan Laut di Katulistiwa (cerita legenda dengan memasukkan unsur maritim), Gugusan Pulau di Katulistiwa (cerita legenda dengan memasukkan unsur bangunan bersejarah), dan Ragam Budaya Katulistiwa (cerita legenda dengan memasukkan unsur bentuk dan filosofi). Acara KJFW tersebut dilaksanakan pada tanggal 7 Juli 2013, mulai pukul 14.00 WIB, dengan rute, diawali dari Kantor Dinas Pariwasata DIY Jalan Malioboro, menuju Taman Budaya Yogyakarta, dengan melintasi Benteng Vredeburg. Jumlah peserta yang berpartisipasi 20 kelompok, dimana setiap kelompoknya terdiri dari 25 orang. Perserta KJFW berasal dari Yogyakarta, Surakarta, dan Magelang.

Acara KJFW 2013 mengusung konsep tematik beberapa di antaranya pakaian yang mengisahkan legenda Dewi Lanjar dan Nyi Roro Kidul, cerita pewayangan yang ditampilkan dalam rangkaian pakaian penuh warna. Acara KJFW 2013 tidak hanya menampilkan pakaian gaya Jawa dan Yogyakarta, karnaval juga menampilkan pakaian khas Dayak, dan Kalimantan. Selain pakaian yang menggambarkan cerita daerah dengan pakaian dan bangunan identitas, juga mengusung warna maritim keindahan dan kekayaan laut Indonesia. 


\section{Karakter Pakaian KJFW 2014}

Tahun ke-8, acara KJFW bertajuk Beruga Jenggala Nusantara, bermakna "Pertemuan Kemegahan Kerajaan Nusantara", dilaksanakan pada hari Minggu 22 Juni 2014 di Jalan Malioboro. Karnaval yang dimulai dari halaman Kantor Dinas Pariwisata DIY melintasi Malioboro bergerak ke Selatan menuju Benteng Vredeburg. Acara KJFW 2014 diikuti 27 kelompok, masing-masing terdiri dari 25 anggota, menampilkan zaman keemasan dan kemegahan kerajaan-kerajaan di Nusantara, seperti: Jawa-Bali, Kalimantan, Sumatera, Sulawesi dan Papua. Sama seperti tahun sebelumnya, masing-masing kelompok mendapatkan pembimbing seorang perancang pakaian, yang disiapkan oleh pihak penyelenggara, selain itu disediakan pula uang bantuan dari panita, yang digunakan untuk persiapan pembuatan pakaian KJFW.

\section{Sejarah Penciptaan Pakaian KJFW}

Berdasarkan pada konsep penciptaan pakaian KJFW, diketahui terdapatnya unsur lain dan berbagai macam alasan yang membuat gaya pakaian karnaval dapat berkembang, diterima, dan menjadi populer pada komunitas, masyarakat, dan pebisnis pakaian. Popularitas pakaian KJFW mengiringi eksistensi dan menghidupkan kembali dunia dongeng dan legenda yang berkembang dalam kehidupan masyarakat. Berjalan beriringan pula secara bersamaan mitos-mitos tentang kepahlawanan, pedoman hidup, nasihat-nasihat yang memberikan semangat dan spirit luar biasa bagi para masyarakat, baik sebagai penonton dan konsumen.

Sejarah sosial melihat persoalan fisik dan nonfisik, sehingga sebagai alat analisis mampu membangun teori-teori yang menguraikan kompleksitas "kesejarahan" sehelai pakaian karnaval. Aspek kesejarahan ini melihat persoalan sosial yang mendorong terjadinya dan pembentukan gaya pakaian karnaval. Sejarah mental terkait erat dengan peran para perancang pakaian yang menghasilkan produk pakaian dengan nilai-nilai, persoalan citra baik dan buruk, bergaya dan tidak, tren dan tidak tren, bermerk dan populer, merupakan justifikasi yang membatasi, sekaligus membedakan jenis pakaian karnaval, serta kelas-kelas sosial (merk) pencipta dan penggunanya.

\section{Sejarah Sosial Penciptaan}

Pakaian KJFW dibentuk berdasarkan transformasi dan komunikasi budaya, kebutuhan eksistensi dan pengakuan identitas, serta membentuk opini masyarakat terhadap peristiwa budaya atau kesenian, termasuk polapola asumsi terhadap pakaian itu sendiri. Kekayaan khazanah masa lampau dalam balutan dongeng, legenda, dan mitos-mitos, dihadirkan dalam konsep kekinian melalui bentuk pakaian karnaval. Pakaian karnaval merupakan wujud kebudayaan sebagai suatu gagasan atau ide-ide ataupun dalam bentuk materi, mengetengahkan nilai-nilai kepercayaan yang dianut oleh masyarakat. Dunia mitos misalnya, kepercayaan terhadap sosok Ratu Pantai Selatan masih dapat dirasakan dan dilihat sampai sekarang ini, melalui wujud pakaian karnaval. Apa yang disajikan oleh para perancang melalui pakaian, mencerminkan keadaan sosial, baik bentuk masa lalu, maupun saat ini.

Konsep dasar penciptaan pakaian KJFW selalu mengacu pada konsepkonsep pemikiran yang mengacu pada film, merujuk pada tokoh-tokoh mitologi; bersumber pada tokoh legenda, mi- 
tos, dan cerita rakyat, termasuk pada tokoh fantasi. Popularitas rujukan dongeng dan mitologi tertentu, merupakan gambaran situasi sosial yang terjadi dalam kehidupan masyarakat Yogyakarta. Pada ranah tertentu, tren ide penciptaan pakaian KJFW merepresentasikan alam serba abstrak, penokohan yang tidak harus menunjuk pada bentuk-bentuk nyata bersumber dari tulisan, dongeng, ataupun cerita sastra lainnya. Kondisi sosial masyarakat yang mempercayai dan meyakini keberadaan tokoh seperti Nyi Roro Kidul, serta diwujudkan dalam konsep pakaian dan tata rias, memberikan gambaran betapa efek cerita dan mitos Ratu Pantai Selatan ini masih berpengaruh pada kehidupan sosial pada masa kini. Jika melihat gagasan Van Peursen, mitos diartikan sebagai cerita yang dapat memberikan pedoman dan arah tertentu kepada sekelompok orang atau masyarakat (1988: 37-38).

Tentu tidak mengherankan, ketika sosok Nyi Roro Kidul masih dihadirkan sebagai tokoh penting pada pelaksanaan KJFW, karena masyarakat masih mempercayai semangat keberadaannya. Konsep-konsep pakaian KJFW adalah gagasan tentang kekayaan nusantara, yang berbicara penanda penting dari suatu kejayaan budaya, identitas daerah, termasuk mitologi, dongeng dan legenda, yang diwujudkan pada pakaian karnaval. Konsep yang serba abstrak (dalam cerita dan gagasan) tersebut diterjemahkan menjadi konsep rupa, dalam wujud seperangkat pakaian karnaval, dilengkapi dengan make up, dan penggunaan aksesori.

Kebudayaan materi dan nonmateri pada pakaian KJFW, merupakan ideide pokok sebagai pijakan awal untuk menentukan bentuk-bentuk pakaian yang akan disajikan kepada masyarakat, baik untuk tujuan promosi ekonomi, atau transformasi konsep-konsep pemikiran tentang kebudayaan itu sendiri. Kebudayaan materi (pakaian KJFW) merupakan hasil perkembangan kebudayaan nonmateri (gagasan) dan tidak ada artinya tanpa kebudayaan nonmateri. Contoh, kalau warisan gagasan, ide, pemikiran tentang sebuah bentuk pakaian KJFW atau tentang konsep kesejarahan, pengetahuan teknologi, dan makna-makna dilupakan, maka pakaian merupakan kumpulan bahan yang tidak bermakna apa-apa, sekumpulan benang, kain, payet, bordir, plastik, atau material lainnya.

Di dalam konteks ini, bagian paling penting dari kebudayaan itu bukan hanya wujud kebendaan saja, tetapi warisan gagasan, ide, dan hasil pemikiran, dalam hal ini berwujud pakaian karnaval. Pakaian karnaval disebut oleh Koentjaraningrat sebagai wujud kebudayaan, yang terdiri atas tiga wujud, yaitu: sebagai suatu kompleks ide-ide, gagasan, nilai-nilai, norma-norma, peraturan; sebagai suatu kompleks aktivitas dan tindakan berpola dari manusia dalam masyarakat; dan sebagai benda-benda hasil kebudayaan manusia (1990:186-187). Kebudayaan tidak dapat ditafsir sebagai sesuatu yang utuh, tetapi sebagai suatu proses dialektika dinamis melalui proses belajar yang terus menerus tanpa henti. Hal ini berarti, kebudayaan selalu berubah dan menyesuaikan diri dengan kebutuhan masyarakat pendukungnya.

\section{$\underline{\text { Sejarah Mentalitas Penciptaan }}$}

Ciri-ciri pokok pemikiran tentang pakaian KJFW terletak pada jenis pakaian yang hanya digunakan pada waktu dan tempat khusus. Pakaian KJFW tercipta dengan memanfaatkan kain-kain tradisional nusantara (kain batik, tenun, dan rajut), yang di dalamnya membawa beraneka ragam pemikiran yang ber- 
sumber dari kebudayaan masyarakat. Pemikiran pakaian KJFW tidak dapat dipisahkan dengan perancang pakaian, pengguna, dan konteks ruang (tempat, waktu, material), termasuk persoalan yang menyangkut material atau bahan, memiliki peran penting dalam penyampaian ideologi. Misalnya, pada ragam hias kain batik yang dipercayai mengandung berbagai falsafah dan nilai filosofi, tidak terkecuali ragam hias pada kain songket, kain rajut, dan anyaman. Pakaian KJFW tidak akan ada tanpa peran seorang perancang, yang tidak saja memperbarui jenis dan bentuk pakaian, termasuk modifikasi dan meningkatkan nilai pada kain-kain tradisional, tetapi juga menyampaikan ideologi dan pesanpesan kultural.

Ideologi pakaian merupakan sesuatu pemikiran yang melandasi latar belakang sosial dan aspek kultur personal (perancang), menyatu pada seperangkat pakaian, dan dapat di terima secara utuh oleh konsumen. Penerimaan gagasan melalui pakaian karnaval, tentu dengan pengetahuan tertentu, sehingga dapat menyamakan persepsi antara perancang dan pengguna. Ideologi dominan yang muncul pada rancangan pakaian karnaval adalah mutlak milik seorang perancang, tetapi tidak terlepas dari konstruksi sosial (industri). Ideologi merupakan perangkat pemberi identitas karakter pada pakaian karnaval, mengklasifikasikan jenis, dan membicarakan tentang pemaknaan terhadap hasil budaya. Menurut Clifford Geertz (1973: 89) budaya merupakan suatu konsep yang dilestarikan dan diwariskan pada generasi selanjutnya, sehingga dengan cara ini manusia dapat berkomunikasi, melestarikan, dan mengembangkan konsep-konsep yang sudah ada. Tentu, setiap pakaian karnaval yang berbeda jenis, berbeda perancang, dan asal daerah, selalu berbeda ideologi dan konsep pemikiran yang tertanam di dalamnya. Melalui proses komunikasi nonverbal, konsep pemikiran tersebut dapat dikomunikasikan secara luas kepada masyarakat.

Di dalam ranah penciptaan pakaian KJFW, terdapat dua kategori perancang, yaitu: mavericks artist dan naive artist. Mavericks artist berpandangan, bahwa dunia senilah yang harus menerima dan beradaptasi terhadap pandangan konvensi kelompok ini, bukan sebaliknya (Howard S. Becker, 1982:241-242). Kelompok naïve artist dapat mencapai gaya tertentu, menciptakan bentuk-bentuk dan genre yang unik dan aneh karena kelompok ini tidak pernah memperoleh dan menginternalisasi kebiasaan visi dan berpikir, seperti layaknya seniman profesional. Naïve artist dikategorikan bukan kelompok seniman, tetapi melakukan praktik dan kerja layaknya seorang seniman (Becker, 1982: 258-269).

Penciptaan pakaian sebagai produk seni populer termasuk dalam kategori maverick artist, kelompok perancang pakaian yang memberontak terhadap konvensi sosial penciptaan pakaian pada umumnya. Para seniman yang tergabung dalam kelompok ini memberikan penanda penting dalam perlawanan konvensi berpakaian. Perancang berperan sebagai orangorang yang memberikan kesempatan berkembangnya jenis pakaian KJFW sebagai proses komunikasi dua arah antara seniman (pencipta produk seni) dan masyarakat penikmat seni. Perlawanan kelompok ini justru memberikan keuntungan dan menghadirkan variasivariasi baru, dan menambah ragam visual pakaian KJFW yang diciptakan.

Secara kolektif, kelompok naïve artist menciptakan produk seni dalam bentuk unik dan aneh, walaupun tanpa pengalaman praktik kerja sebagai seorang seniman profesional, sebagai 
usaha berkomunikasi dan menunjukkan sikap. Setiap rancangan pakaian yang dihasilkan, dalam ranah yang terbatas mempunyai kepentingan dan tujuan. Tujuan tersebut dapat berupa ilmu pengetahuan, penciptaan tren, dan kepentingan ekonomi, dengan beraneka ragam bentuk gaya pakaian seorang tokoh. Gaya pakaian yang dihasilkan merupakan gagasan pemikiran perancang, ketika dipresentasikan pada masyarakat penonton akan menimbulkan bermacam-macam reaksi. Ketika terjadi perlawanan melalui satu jenis pakaian pakaian KJFW, dapat dibaca atas hadirnya perbedaan pemikiran perancang dengan konvensi sosial yang berlaku pada masyarakat, atau ketidakpahaman (keegoisan) seniman mavericks itu sendiri.

Nä̈ve artist tidak termasuk dalam kelompok seniman (profesional), tetapi melakukan praktik dan kerja layaknya seorang seniman. Dengan demikian, penilaian terhadap karya seni yang dihasilkan dilakukan melalui pengamatan dan penelitian, untuk menggeneralisasi konsep pemikiran berdasarkan karya seni. Setiap perwujudan karya seni yang terbungkus dengan beraneka ragam medium akan menyampaikan nilai-nilai tertentu, yaitu: pertama, nilai penampilan yang melahirkan benda seni atau artefak, terdiri atas nilai bentuk dan nilai struktur; kedua, nilai isi berupa nilai-nilai pengetahuan (kognisi), nilai rasa, intuisi atau bawah sadar manusia, nilai gagasan, nilai pesan atau nilai hidup, seperti: nilai moral, nilai sosial, dan nilai religi; ketiga, nilai pengungkapan untuk menunjukkan adanya nilai-nilai bakat pribadi, nilai keterampilan, dan nilai medium yang digunakannya (Prawira, 2000: 12).

\section{Pemaknaan pakaian KJFW}

Pakaian KJFW dijadikan sebagai alat untuk pembentukan citra dan usaha memaknai dalam sudut pandang yang berbeda. Citra dan makna merupakan bagian dari konotasi. Pameran pakaian melalui karnaval memang dalam rangka promosi dan pembangunan citra-citra positif, untuk memberikan pengetahuan dan pendidikan budaya kepada masyarakat, yang pada akhirnya berujung pada tujuan-tujuan pasar dan ekonomi. Pada dimensi lain, pameran pakaian (KJFW) merupakan cara-cara yang dilakukan dengan aturan-aturan, untuk memberikan pemahaman, atau bahkan, dalam usaha untuk menarik minat orang lain untuk meniru, sehingga apa yang dipromosikan dapat diterima. Dalam ranah sosial, tentu dengan sendirinya terbentuk citra-citra yang mengangkat kelompok, pihak perhotelan dan jasa, organisasi masyarakat dan komunitas, serta pihak-pihak lain yang ikut serta dalam pelaksanaan acara KJFW. Karena pencitraan merupakan persoalan bagaimana dianggap keberadaannya dan di pandang memiliki kelayakan untuk berada dalam kelompok masyarakat sosial tertentu.

Malcolm Barnard mengungkapkan, pakaian digunakan untuk menunjukkan nilai sosial atau status, dan orang sering membuat penilaian terhadap nilai sosial, berdasarkan atas apa yang dipakai oleh orang lain (Malcolm Barnard, 2009: 86). Di dalam konteks promosi dan pembentukan citra, apa yang ditampilkan oleh pakaian karnaval, merupakan penampang yang jelas bagi konsumen untuk menentukan pilihan gaya pakaian, termasuk pemilihan atas banyaknya pilihan perancang pakaian di Yogyakarta. Nilai sosial atau status yang diangkat pada pakaian KJFW, merupakan representasi identitas tertentu kepada masyarakat sosial, baik sesama 
perancang pakaian, ataupun orang lain sebagai penonton dan konsumen. Nilai sosial menjadi penting untuk merkmerk dagang, semakin tinggi nilai sosial sebagai hasil pameran pakaian karnaval, semakin luas jangkauan sosial (termasuk jumlah masyarakat dan penonton yang menyaksikan), akan membuat semakin banyak keuntungan ekonomi yang didapatkan. Dengan penilaian-penilaian sosial yang dilakukan oleh kelompok-kelompok tertentu, mampu memberikan dampak positif dan negatif terhadap komunitas atau seseorang perancang pakaian. Nilai sosial atau status inilah yang pada akhirnya berbicara tujuan dan kepentingan penciptaan salah satu jenis gaya pakaian karnaval. Pakaian secara lahiriah merupakan penanda penting, untuk membedakan atau menyamakan seseorang dengan orang lain (Jennifer Craik, 1993: 4). Hal membedakan dan menyamakan dalam konteks sosial, merupakan pembicaraan gaya pakaian dalam konteks visual pakaian. Gaya modifikasi kebaya, gaya pakaian panjang dan tertutup, merupakan pilihan bentuk desain. Pada pakaian karnaval sebagai karya seni merupakan sebuah penanda, diciptakan untuk membawa makna-makna yang ingin dikomunikasikan oleh perancang kepada konsumen atau penonton, atau penikmat karya seni. Makna tersebut akan dapat diterima dengan baik, jika seseorang mampu membaca dan memahami presentasi visual yang muncul pada suatu karya seni.

Pencitraan sebagai makna konotasi, bukanlah persoalan baru pada pakaian dalam konteks sosial. Pencitraan ini merupakan persoalan yang berhubungan dengan rasa dan sensasi yang diterima oleh seseorang atau sekelompok orang. Citra diri dan merk pakaian menyangkut wilayah status seseorang pada kehidupan atau kelompok masyarakat sosial tertentu. Ske- ma citra sebagian besar didefinisikan sebagai kerangka mental yang tidak sadar dari suatu bentuk, tindakan, dimensi, yang terus berulang, bersumber dari persepsi dan perasaan (Marcel Danesi, 2010: 95). Persepsi yang diterima oleh setiap penonton sebagai konsumen akan berbeda-beda, sehingga menghasilkan asumsi-asumsi yang berbeda, mengenai makna-makna yang terkait dengan usaha untuk mencitrakan pakaian. Pencitraan adalah suatu cara yang dilakukan untuk mendapatkan prestasiprestasi dalam kehidupan masyarakat sosial, dengan harapan dapat diakuinya peran dan keberadaan seseorang dalam kelompok masyarakat (menjadi tren). Dengan diakuinya seseorang dalam konteks masyarakat, dapat menunjukkan keberadaan dan kehadirannya, yang dijadikan sebagai sebuah sistem pencitraan, sehingga status dalam kehidupan sosial dapat dihargai oleh orang lain.

Pada ranah lain, konotasi dapat dibaca sebagai makna-makna kedua pada pakaian karnaval, karena selain konotasi terdapat makna denotasi atau hal yang menyangkut persoalan fisik pakaian. Misalnya, pada pakaian gaya Nyi Roro Kidul dapat diterjemahkan sebagai sebuah produk seni yang diciptakan dengan mengacu pada mitologi masyarakat Jawa, khususnya daerah pantai Selatan. Nyi Roro Kidul, oleh sebagian masyarakat dipercaya sebagai penguasa atau ratu dari laut Selatan, sekaligus menguasai seluruh kehidupan makhluk halus di lokasi tersebut. Beberapa orang beranggapan, keyakinan terhadap Nyi Roro Kidul sengaja dimunculkan sebagai bentuk legitimasi akan Kerajaan Mataram. Keraton Surakarta menyebutnya sebagai Kanjeng Ratu Ayu Kencono Sari. Selain Nyi Roro Kidul, terdapat pula Nyi Blorong, yang dipercayai sebagai panglima perangnya. Nyi Blorong merupakan sosok siluman 
ular, memiliki hawa nafsu, menyenangi orang-orang yang meminta kekayaan, dengan imbalan hubungan seksual dan beberapa hal lain.

Makna konotasi pakaian karnaval memberikan ruang-ruang untuk melakukan pendidikan budaya dan etnik kepada para konsumen, tidak terkecuali pembelajaran ekonomi, seni rupa, dan ilmu pengetahuan lainnya. Tidak ketinggalan pembelajaran untuk peduli pada lingkungan, seperti yang terjadi pada pelaksanaan acara KJFW tahun 2010, bagaimana masyarakat diajak untuk secara bersama-sama memanfaatkan dan mengelola limbah plastik secara bijak. Ketika pelaksanaan, pakaian karnaval diciptakan dari olahan limbah plastik yang sudah tidak terpakai, seperti: bungkus makanan cepat saji, kantong plastik, bungku produk, dan beberapa material lain yang berbahan plastik. Nilai edukasinya terletak pada kepedulian terhadap lingkungan, bagaimana meningkatkan kreativitas seseorang dengan tujuan untuk menciptakan bentuk pakaian karnaval, dan memberikan edukasi betapa pentingnya untuk peduli pada bumi. Melalui pendidikan budaya, diharapkan tercapai pula karakter-karakter masyarakat yang peduli pada isu pemanasan global dan keberlangsungan kehidupan ekosistem pada alam.

Konotasi melihat persoalan pakaian sebagai alat komunikasi, seperti yang dibicarakan oleh Malcolm Barnard, bahwa:

Pakaian yang kita kenakan membuat pernyataan tentang busana kita. Bahkan jika kita bukan tipe orang yang terlalu peduli soal busana, orang yang bersua dan berinteraksi dengan kita tetap akan menafsirkan penampilan kita, seolah-olah kita sengaja membuat suatu pesan. Pernyataan ini membawa kita pada fungsi komunikasi dari pakaian yang kita kenakan dalam kehidupan sehari-hari, baik dalam suasana formal maupun informal. Pakaian dipandang memiliki suatu fungsi komunikatif. Busana, pakaian, kostum, dan dandanan adalah bentuk komunikasi artifaktual. Komunikasi artifaktual didefinisikan sebagai komunikasi yang berlangsung melalui pakaian, dan penataan pelbagai artefak, misalnya, pakaian, dandanan, barang perhiasan, kancing baju, atau furnitur di rumah dan penataannya, ataupun dekorasi ruangan. Karena fashion atau pakaian menyampaikan pesan-pesan nonverbal, ia termasuk komunikasi nonverbal (Barnard, 2009: vi-vii).

Dengan demikian, pakaian karnaval tidak terlepas dari fungsi sebagai alat komunikasi secara nonverbal. Kepentingan penyelenggara, perancang pakaian, dan pebisnis pakaian dapat bertemu pada satu titik, saat apa yang ingin dikomunikasikan dapat tercapai dan dipahami oleh masyarakat dan konsumen. Tercapai secarai edukasi budaya, tercipta tren pakaian, dan menjaga keberlangsungan kehidupan industri pakaian, sebagai bagian dari ekonomi kreatif.

\section{SIMPULAN}

Sejarah pakaian KJFW di Yogyakarta memperlihatkan persoalan pentingnya peran-peran komunitas untuk menciptakan gaya. Acara KJFW dilaksanakan untuk memajukan industri pakaian dengan menciptakan pakaian berkualitas, sehingga dapat menekan laju impor pakaian asing, meningkatkan produktifitas pakaian, menciptakan tren mode pakaian, baik skala lokal, nasional, dan internasional. Peran serta perancang pakaian, komunitas, lembaga -lembaga, dan pemerintah, saling bersinergi untuk memajukan industri tekstil, memberi lapangan pekerjaan, 
Makna dan Struktur ... - Deni Setiawan

dan meningkatkan kesejahteraan masyarakat. Selain sebagai produk industri, pakaian karnaval tidak dapat dipisahkan sebagai produk budaya, yang memiliki makna dan strukturstruktur tersendiri. Makna yang bersumber dari legenda, cerita rakyat, dan mitologi, memiliki spirit luar biasa untuk diceritakan kembali melalui wujud pakaian karnaval. Sumber ide penciptaan dan pakaian secara fisik, merupakan struktur-struktur pakaian karnaval. Pada saat pakaian KJFW diciptakan, pemaknaan ini akan berhenti ketika tidak ada respon dari orang lain (pengguna). Struktur pemaknaan akan muncul pada saat pakaian digunakan atau bersentuhan dengan lingkungan masyarakat sosial, dengan demikian konsep-konsep pada pakaian KJFW akan kembali terbaca oleh orang lain, untuk memperlihatkan hubungan antara perancang dan pengguna pakaian, antara pakaian dan lingkungan (komunitas).

Dari aspek kesejarahan memperlihatkan desakan kondisi sosial yang mempengaruhi penciptaan pakaian karnaval. Kepercayaan masyarakat Yogyakarta terhadap mitos-mitos tradisional yang berkembang, dipresentasikan ke dalam bentuk pakaian karnaval. Mitos Nyi Roro Kidul, ataupun beberapa bentuk lain, disajikan menjadi sebuah pertunjukan pakaian dengan nilai kekinian yang menarik dan difungsikan untuk meningkatkan nilai jual kain tekstil tradisional. Pada aspek masyarakat pendukung sebagai bagian sejarah mental, menunjukkan keberadaan perancang pakaian dalam dua kelompok besar, mavericks artist dan naïve artist, yang berperan untuk menciptakan dan mengkreasikan bentuk-bentuk baru pakaian karnaval di Yogyakarta.

\section{DAFTAR PUSTAKA}

Barnard, Malcolm. 2009. Fashion sebagai Komunikasi: Cara Mengkomunikasikan Identitas Sosial, Seksual, Kelas, dan Gender. Cetakan ke-2. Yogyakarta: Penerbit Jalasutra.

Barton, Will dan Andrew Beck. 2010. Bersiap Mempelajari Kajian Komunikasi. Cetakan Pertama. Yogyakarta: Penerbit Jalasutra.

Becker, Howard S. 1982. Art Worlds. Berkeley and Los Angeles, California: University of California, $\mathrm{Ltd}$.

Craik, Jennifer. 1993. The Face Of Fashion: Cultural Studies in Fashion. London: Routledge.

Danesi, Marcel. 2010. Pesan, Tanda, dan Makna: Buku Teks Dasar Mengenal Semiotika dan Teori Komunikasi. Yogyakarta: Penerbit Jalasutra.

Geertz, Clifford. 1973. The Interpretation of Cultures. New York: Basic Books, Inc., Puhlishers.

Hauser, Arnold. 1982. The Sociology of Art. Chicago \& London: University of Chicago.

Kartodirdjo, Sartono. 2002. "Teori Sejarah dan Masalah Historiografi", dalam Dari Samudera Pasai ke Yogyakarta: Persembahan kepada Teuku Ibrahim Alfian. Jakarta: Yayasan Masyarakat Sejarawan Indonesia dan Sinergis Press.

Koentjaraningrat. 1990. Pengantar Ilmu Antropologi. Jakarta: PT. Rineka Cipta, Cetakan ke-8.

Levi-Strauss, Claude. 2007. Antropologi Struktural. Yogyakarta: Penerbit Kreasi Wacana.

Morris, Desmond. 2002. Peoplewatching: The Desmond Morris Guide to Body Language. London: Vintage Books.

Peursen, C.A. Van. 1988. Strategi Kebudayaan.Yogyakarta: Penerbit Kanisius.

Prawira, Nanang Ganda. 2000. "Kriya dan Rekahias Baduy: Bentuk, Fungsi, Motif, Simbol dan Makna: Kriya dan Rekahias Masyarakat Baduy di Desa Kanekes, Kecamatan Leuwidamar, Kabupaten Lebak". Jurnal Seni Rupa dan Desain, Bandung: STISI, Volume 1, Nomor 1, Agustus, 2000: 12. 
Paramita Vol. 25, No. 2 tahun 2015

Syukur, Muhammad, dkk. 2014. "Transformasi Penenun Bugis-Wajo Menuju Era Modernitas". Jurnal Paramita, Volume 24, Nomor 1, 63-77.
Warto. 2014. "Revitalisasi Kesenian Kethek Ogleng untuk Mendukung Pengembangan Pariwisata dan Kabupaten Wonogiri". Jurnal Paramita, Universitas Negeri Semarang, Volume 24, Nomor 1: 47-62. 